\title{
Analytical Study of the Organisational Culture- Related Practices in Colleges of Education in Western and Central Regions of Ghana
}

\author{
Dr Francis Hull Adams* \\ Holy Child College of Education Takoradi, Department of Social Science, Box 245 Takoradi \\ Jacob Issaka \\ Jasikan College of Education, Department of Arts and Social Sciences \\ Box 14, Jasikan Ghana \\ Ama Mbeaba Quarshie \\ Holy Child College of Education Takoradi, Department of Social Science, Box 245 Takoradi \\ Barbara Amoako Kissi \\ Accra College of Education, Accra Ghana
}

\begin{abstract}
This study was undertaken to ascertain the organisational culture related practices in Colleges of Education in the Central and Western Regions of Ghana. The conduct of the research was guided by two research questions. The main research instrument used was a questionnaire. Both open-ended and close-ended questions were used. The statistical tools used for the analysis were Frequency, Percentage distributions, Mean and Standard deviations and ANOVA.The study revealed that in spite of the elevation of the Colleges of Education to the tertiary level, most of the practices of the colleges are still based on second cycle organisational culture. The elevation of the Colleges of Education to the tertiary status has imposed challenges on discipline as teacher trainees perceive the rules and regulations of the Colleges as being too strict. Recommendations made include: Measures should be put in place by College authorities to create democratic, open and transparent administration to ensure that both students and tutors operate without fear of being maligned or discriminated against in the performance of their duties. College principals are enjoined to put in place pragmatic measures to facilitate governance of the colleges as tertiary institutions and to ensure that second cycle cultural practices are eschewed. Keywords: Organisational Culture, Colleges of Education, Cultural Practices, Tertiary Status
\end{abstract}

DOI: $10.7176 /$ RHSS/11-13-01

Publication date:June $30^{\text {th }} 2021$

\subsection{Introduction}

Students in the teacher training colleges (now colleges of education) in Ghana have the challenge of demonstrating discipline in every aspect of their lives. This is because they are teacher trainees who will be teaching pupils in the basic schools after training. They are therefore expected to lead exemplary lives, obey College's rules and regulations and respect authority. Mireku (1998) explained that discipline is strictly enforced with rules and regulations over attendance, dressing, exeats, response to bells and punctuality, doing exercises, competitions and punishments. He observed that life in the colleges is controlled giving students very little opportunities to be responsible for their own affairs.

The tutors in the colleges have more arduous tasks as they are supposed to be role models for the trainees (Acheampong, 2003; Lumpkin, 2008; Mireku, 1998). The tutors are, therefore, expected to exhibit this character by their sense of commitment to the school in terms of attending lectures regularly and punctually, playing their roles effectively as counselors and advisors and working towards the attainment of the mission and vision statements of the College.

Student leaders and College administrators equally have the duty to ensure that both students and tutors conduct themselves in the manner in tune with the school culture which can help promote the school in a very positive manner. Students of the public Colleges of Education in Ghana are torn between leading strict disciplined lives as pertains in the Colleges on one hand and leading permissive lives as pertained in some of the tertiary institutions such as the universities and the polytechnics on the other hand. This general feeling of students have been necessitated by the Colleges of Education Act 2012 (Act 847) which elevated all public Colleges of Education in Ghana to tertiary status. The changes in the status of the Colleges of Education have resulted in changes in the collective behavior of students as well as changes in the corporate culture of the Colleges.

Students in the colleges hold the view that college authorities should not restrict their movements too much 
(Acheampong, 2003). Acheampong assessed that many student teachers felt that the strict college rules and regulations undermine their personal self-worth and ability to exercise control over their lives in college. He further revealed that trainees have a lot of misgivings concerning their training. They believe that they should be allowed the freedom to go out anytime without taking permission or exeat. Most of them think that they have the right to decide on what to wear to lectures instead of using uniform. Some express the view that they reserve the right to decide on which lecture to attend even though they have registered for the courses. These assertions are supported by a study conducted by Adams and Opare (2013) in an all-female college of education in Ghana in which both past and current students of the College complained of poor treatment of students by the college authorities. According to them, these and many other challenges have posed a big problem to students' leadership, tutors and College administrators in their bid to enforce discipline. Should traditions and norms of the Colleges be strictly followed even in the face of the new status and 'freedoms' of the Colleges of Education or should the organisational culture of the Colleges be reviewed to meet the new status of the Colleges.

In view of the new status of the Colleges of Education and the concomitant leadership challenges posed, it has become necessary to investigate into how changes in the existing school culture of the Colleges of Education following their elevation to the tertiary status influence leadership roles and vice-versa. A review of available literature indicates that some studies have been conducted on school climate and principal's management style (Arshad, 2003; Gursel and Negis-isik, 2013; Yadessa, 2014). Other studies focused on the establishment of organisational culture in education (Kruger 2003; Mentz 1992) and the role of the leader (Kapp 2000; Waters\& Kingston 2005). However, there have not been any known studies regarding the organisational culture of colleges of education in their current status. This calls for concern. The following pseudonyms were used to represent the target colleges throughout the study:

SOMCOE- State-Owned Mixed College of Education

FBMCOE- Faith-Based Mixed College of Education

FBSSCOE- Faith -Based Single Sex College of Education

\subsection{Objectives of the Study}

The study was aimed at attaining the following specific objectives:

1. To find out the organisational culture related practices in the Colleges of Education

2. To assess the extent to which tutors and students adhere to the organisational culture related practices in the Colleges of Education

3. To assess the differences in teacher trainees' views on organisational culture related practices among the colleges.

\subsection{Research Questions and Hypotheses}

The study was guided by two questions and one hypothesis

1. What are the organisational culture related practices in the Colleges of Education?

2. To what extent do tutors and students adhere to the organisational culture related practices in the Colleges of Education?

Hypothesis: There are no significant differences between teacher trainees' views on organisational culture related practices among the Colleges of Education

\subsection{Methodology}

The study adopted mainly a quantitative cross-sectional design with a survey. The target population for the study consisted of all teacher trainees and tutors in the Colleges of Education in Central and Western Regions of Ghana. According to Kumar (2011) a target population is that population which the researcher wants to generalize results. The accessible population for the study was made up of selected teacher trainees from FBMCOE, SOMCOE and FBSSCOE. A census of tutors in the three colleges was used for the study. The sample size of the study consisted of 568 respondents, (Students: 450 and Tutors: 118.) 24\% of both tutors and students population. The main research instruments used were Questionnaire and Interview Guide. Both openended and closed ended questions were used. Questionnaires were used because it is one of the reliable ways of getting information from literate population.

\subsection{Results and Discussion}

3.1 Objective 1: Organisational culture related practices in the Colleges of Education Selection and Orientation of Student Leaders and Tutors

The administrative structure in educational institutions makes provision for student leadership. In line with this provision, Students' Representative Councils (SRC) are found in most educational institons. In most cases, the representatives are elected by the students themselves after school administration nominates candidates for various positions. In other cases, students are allowed to nominate and elect their own leaders. Student leaders 
exhibit some unique characteristics that endear them to the hearts of their colleagues.

Selection of leaders in the Colleges of Education, both students and tutors is one of the practices that this study intended to investigate. In most educational institutions, student leaders are either handpicked by school authorities or elected by the student population. What is the practice in the Colleges of Education? This question has been answered by the data in Table 1. More so, how heads of departments are selected and as to whether both student leaders and tutors receive some form of orientation when they gain leadership status. All these have been addressed in Table 1.

Table 1: Mode of Selecting Student leaders/ Selection and Orientation of Heads

\begin{tabular}{lllll}
\hline Item/Responses & Strongly Disagree & Disagree & Agree & Strongly Agree \\
\hline SRC leaders are elected & & & & \\
Faith-Based Single Sex College of Education & 3.6 & 6.4 & 56.5 & 33.6 \\
State-Owned Mixed College of Education & 2.9 & 31.4 & 52.1 & 13.6 \\
Faith-Based Mixed College of Education & 2.1 & 21.4 & 55.0 & 21.4 \\
Total & 2.9 & 19.7 & 54.5 & 22.9 \\
Leadership training is offered to new prefects & & & & 33.6 \\
Faith-Based Single Sex College of Education & 3.0 & 7.0 & 56.4 & 10.7 \\
State-Owned Mixed College of Education & 2.1 & 20.7 & 66.4 & 12.9 \\
Faith-Based Mixed College of Education & 5.0 & 17.1 & 65.0 & 19.1 \\
Total & 3.4 & 14.9 & 62.6 & 00.0 \\
Heads of departments are elected & & & & 00.0 \\
Faith-Based Single Sex College of Education & 100.0 & 00.0 & 00.0 & 00.0 \\
State-Owned Mixed College of Education & 100.0 & 00.0 & 00.0 & 00.0. \\
Faith-Based Mixed College of Education & 100.0 & 00.0 & 00.0 & 00.0 \\
Total & 100.0 & & & \\
& & & & 00.0 \\
Mentorship training is offered to new tutors & & 60.0 & 00.0 & 00.0 \\
Faith-BasedSingle Sex College of Education & 40.0 & 20.0 & 60.0 & 00.0 \\
State-Owned Mixed College of Education & 20.0 & 40.0 & 10.0 & 00.0 \\
Faith-Based Mixed College of Education & 50.0 & 40.0 & 23.3 & 00.0 \\
Total & 36.7 & & & \\
\hline Source: Field Survey, & & & &
\end{tabular}

Source: Field Survey, (2020)

Table 1 focused on four issues concerning mode of selecting leaders and heads of departments. Respondents were made to indicate /whether they agree, strongly agree, disagree or strongly disagree to the following statements: SRC leaders are elected in my College; leadership training is offered to new prefects; heads of departments are elected and mentorship training is offered to new tutors.

The question as to whether SRC leaders are elected in the three Colleges received an overwhelming 'Yes'. This can be seen from Table 4 where 54.5 percent of the entire respondents selected 'Agree'. This trend of view is supported by available literature. In most tertiary institutions in Ghana avenues and opportunities are created for students to elect their own leaders to lead them (Appiah, 2012; CoE Act, 847; CUC, 2015). The issue of leadership training being offered to new prefects also received an affirmative response from the study participants. Majority of the respondents (65.6\%) selected 'Agree'. In another development, the tutor respondents however, strongly disagreed with the statement that heads of departments are elected in the three Colleges as opposed to appointment. It was a unanimous disagreement (100\%). This raises a legitimate question of how the heads of departments are selected if they are not elected? It can be inferred from the responses and further discussions with the respondents that Heads of departments could be appointed by the Principals. This conclusion is however supported by what the Harmonised statutes of the Colleges of Education says, that "each department in the College shall have an appointed head of department" (Harmonised Statutes of CoE, 2013). The Statutes did not outline the processes involved in the appointment and also did not indicate the appointing authority.

The last issue captured in Table 2 is about whether mentorship training is offered to new tutors. Here, $40 \%$ selected; Disagree' with 36.7\% selecting 'strongly disagree'. However, case by case responses of the three Colleges gives a split in terms of the views. Whiles views from respondents in SOMCOE upheld the statement by $60 \%$, views from respondents in FBSSCOE and FBMCOE rejected the assertion by $60 \%$ and $50 \%$ respectively. The Colleges of Education Cultural Web based on Johnson and Sholes (1988) identifies routines and rituals as integral part of an organisation. Some of the common routine practices outlined by the Web includes elections of prefects and orientation and training of prefects and mentors for tutors. These practices are supported by the findings explained above. 


\subsection{Ways by which Students' Representative Council (SRC) and tutors work}

Tutors and student leaders are supposed to work hand-in hand to promote discipline and conducive environment for studies in educational institutions especially in tertiary institutions where a lot of leadership roles are assigned to student leaders. This collaboration is expected to help students to build leadership skills so that without teachers they can take decisions and enforce them in the interest of the institutions. It will also prepare students to learn to work without staff supervision. Table 2 assesses the issues raised concerning student leaders' ability to enforce their decisions as well as their abilities to work without staff supervision. Again, the information in Table 1 further explains whether tutors in the Colleges have authority to enforce College rules and regulations and also whether they could freely express themselves on administrative issues.

Table 2: How SRC Leaders and Tutors Work

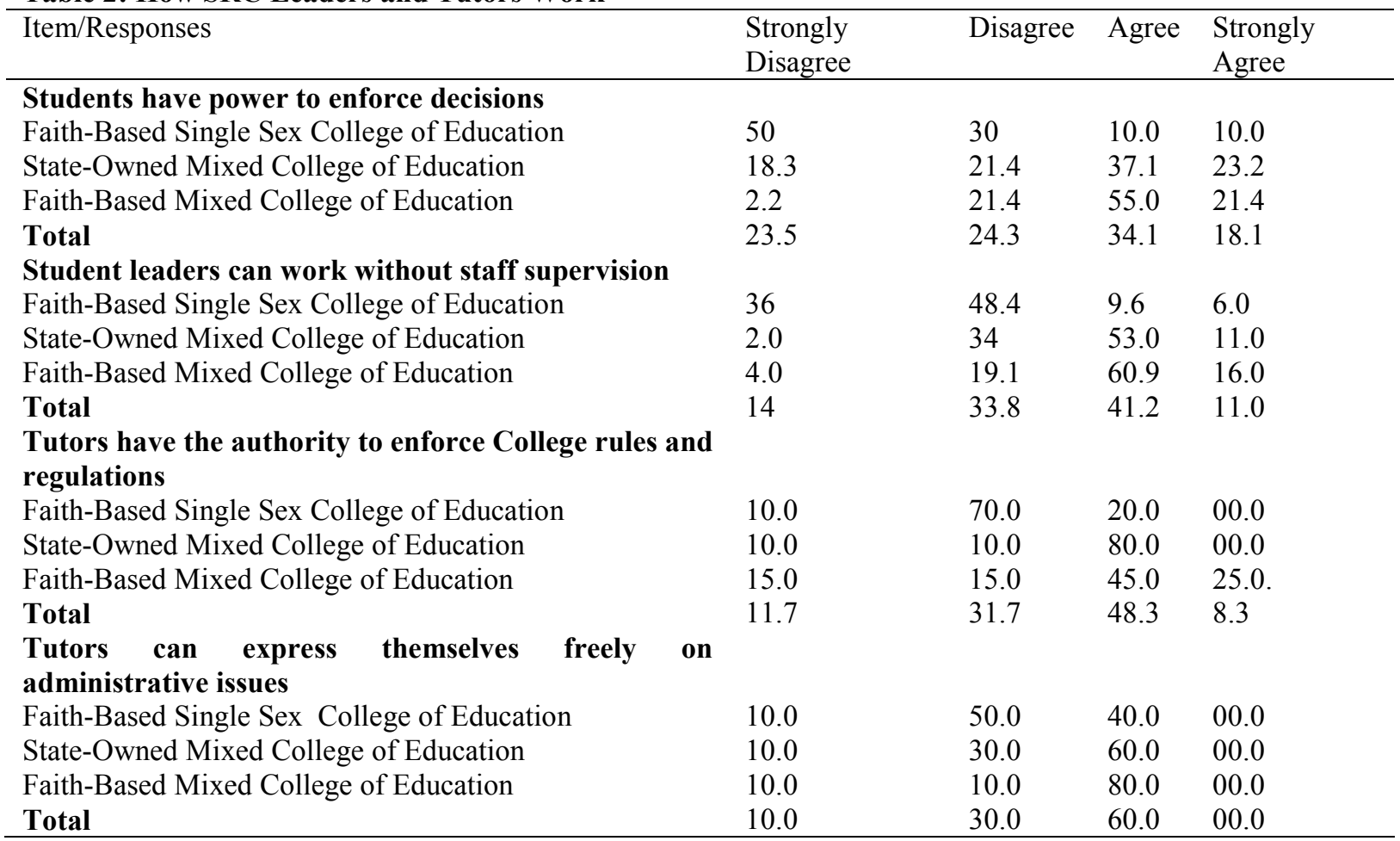

Source: Field Survey, (2020)

Data in Table 2 indicates that generally, students' leaders in the Colleges of Education have authority to enforce decisions they take. This is so because 34.1 percent and 18.1 percent of the respondents selected 'Agree' and 'Strongly Agree' respectively to the issue. However, College by College analyses show that apart from FBSSCOE which disagreed to the statement, SOMCOE and FBMCOE agreed. Based on the data, it can be inferred that there seems to be a problem with trainees of FBSSCOE with regards to the SRC having power to enforce its decisions. However, SOMCOE and FBMCOE trainees admitted their SRCs can enforce decisions they take. Views expressed by SOMCOE and FBMCOE trainees in this regard is supported by the Ghana Education Service which upholds the view that the SRC should serve on established Committees of the school and among others enforce decisions of the body in the areas of students' welfare, discipline, compound, entertainment and sports (GES, 2010).

Responses of trainees to the second statement that 'student leaders can work without staff supervision' showed a general agreement. Majority of the respondent (52.2\%) opted for the options 'Agree' and 'Strongly agree'. Here again FBSSCOE appeared to be the odd one out as FBMCOE and SOMCOE trainees admitted they could operate much better without any form of supervision from tutors.

Tutors in the Colleges were asked whether they have authority to enforce College rules and regulations on their own. The four-point scale responses were categorized into two, namely 'Agree' and 'Disagree'. Responding to the question, 31.4 percent of the tutor respondents opted for 'Disagree' whiles 56.6 percent went for 'Agree and disagree respectively. The views expressed by the tutors do not agree with Johnson and Sholes' (1992) Cultural Web in which under control systems, the Students Representative Council and tutors are supposed to show leadership by enforcing rules and regulations to ensure order in the institution. Mintah, (2013) however agreed with the findings on the grounds that discipline should be strictly enforced by tutors and student leaders with rules and regulations over attendance, dressing, exeats, response to bells, punctuality and punishments.

Majority of the respondents in FBSSCOE disagreed that tutors could express themselves freely. SOMCOE 
and FBMCOE however, agreed that tutors could express themselves. This means conditions in SOMCOE could be similar to that of FBMCOE. Again, leadership style portrayed by the institutions could be a factor. The deduction from Table 2 is that in FBSSCOE, tutors cannot freely express themselves whiles in SOMCOE and FBMCOE tutors can freely express themselves. The freedom for people to freely express themselves in institutions of higher learning is good for the constructive build-up of that institution. A school which promotes democratic principles affords opportunities for both students and staff to express themselves freely, allows for a free flow of information where everyone knows what is going on and encourages suggestions and participations among staff and students (Mondal, 2016; Jabir \&Maejir 2015).

\subsection{Decision-Making}

Decision-making is a very important aspect of every organization. It determines the system of administration put in place, the people who are involved in administration and the extent to which people's participation in administration influences the direction of the institution. In higher institutions of learning such as Colleges of Education, the committee system is expected to operate where work is divided among the staff that belongs to various committees to do. Decision-making for this study focused on six main areas. First, representation of SRC on College Committees. Secondly, the need to solicit students' views on important issues. Third, the incorporation of students' views in decisions of administration and the representation of tutors on Council committees. Others include soliciting tutors' views and incorporating them in final decisions. Table 3 presents the analysis of responses from both tutors and students

Table 3: Decision-Making

\begin{tabular}{|c|c|c|c|c|}
\hline Item/Responses & $\begin{array}{l}\text { Strongly } \\
\text { Disagree }\end{array}$ & Disagree & Agree & $\begin{array}{l}\text { Strongly } \\
\text { Agree }\end{array}$ \\
\hline \multicolumn{5}{|l|}{ Representation of SRC on College Committees } \\
\hline Faith-Based Single Sex College of Education & 5.7 & 24.3 & 59.3 & 10.7 \\
\hline State-Owned Mixed College of Education & 12.3 & 12.0 & 52.1 & 23.6 \\
\hline Faith-Based Mixed College of Education & 6.1 & 23.2 & 70.0 & 0.7 \\
\hline Total & 8.0 & 19.8 & 60.5 & 11.7 \\
\hline \multicolumn{5}{|c|}{$\begin{array}{l}\text { College administration seeks views of students on } \\
\text { important issues }\end{array}$} \\
\hline Faith-Based Single Sex College of Education & 33.6 & 60.7 & 5.7 & 00.0 \\
\hline State-Owned Mixed College of Education & 00.0 & 10.5 & 80.00 & 9.5 \\
\hline Faith-Based Mixed College of Education & 14.8 & 63.7 & 16.8 & 4.7 \\
\hline Total & 16.1 & 45.0 & 34.2 & 4.7 \\
\hline \multicolumn{5}{|c|}{$\begin{array}{l}\text { Incorporation of student's views into decisions of } \\
\text { administration }\end{array}$} \\
\hline Faith-Based Single Sex College of Education & 12.9 & 71.4 & 11.6 & 4.1 \\
\hline State-Owned Mixed College of Education & 12.8 & 69.4 & 13.5 & 4.3 \\
\hline Faith-Based Mixed College of Education & 13.6 & 60.1 & 20.0 & 6.3 . \\
\hline Total & 13.0 & 66.0 & 15.0 & 6.0 \\
\hline \multicolumn{5}{|c|}{ Tutors are well represented on Council Committees } \\
\hline Faith-Based Single Sex College of Education & 00.0 & 20.0 & 70.0 & 10.0 \\
\hline State-Owned Mixed College of Education & 00.0 & 10.0 & 70.0 & 20.0 \\
\hline Faith-Based Mixed College of Education & 10.0 & 30.0 & 40.0 & 20.0 \\
\hline Total & 3.3 & 20.0 & 60.0 & 16.7 \\
\hline \multicolumn{5}{|c|}{$\begin{array}{l}\text { College authorities seek views of tutors on important } \\
\text { issues }\end{array}$} \\
\hline Faith-Based Single Sex College of Education & 10 & 70 & 20 & 00.0 \\
\hline State-Owned Mixed College of Education & 10 & 30 & 60 & 00.0 \\
\hline Faith-Based Mixed College of Education & 30 & 50 & 20 & 00.0 \\
\hline Total & 16.7 & 50.0 & 33.3 & 00.0 \\
\hline \multicolumn{5}{|c|}{$\begin{array}{l}\text { Views of tutors are incorporated into final decisions of } \\
\text { administration }\end{array}$} \\
\hline Faith-Based Single Sex College of Education & 10.0 & 70 & 20 & 00.0 \\
\hline State-Owned Mixed College of Education & 00.0 & 60 & 40 & 00.0 \\
\hline Faith-Based Mixed College of Education & 00.0 & 70 & 30 & 00.0 \\
\hline Total & 3.3 & 66.7 & 30 & 00.0 \\
\hline
\end{tabular}

Source: Field Survey, (2020)

Responding to the question of whether students are represented on College Committees, the student 
respondents affirmed that they are duly represented on all school committees $(60.5 \%$ agreed whiles $11.7 \%$ strongly agreed). A total of only $27.8 \%$ settled on Disagree and strongly disagree. So it is clear from the statistics that in all the three Colleges used for this study, students were adequately represented on College Committees. Interesting views were expressed on the second item which enquired from the trainees whether College administration seeks views of students on important issues. Majority of the respondents disagreed and strongly disagreed respectively (61.1). Whiles, $38.9 \%$ of the respondents also agreed and strongly agreed to the statement. FBMCOE and FBSSCOE disagreed whiles respondents from SOMCOE agreed to the statement. This means in FBSSCOE and FBMCOE authorities hardly seek for students' views on important College issues. However, the facts that in SOMCOE students' views are sought for on important issues is a good practice for the College. Students would feel involved in decision-making and that could help build good relationship between students and tutors which is essential for academic exploits. The views expressed by trainees of SOMCOE are corroborated by one of the findings of a research conducted by Kibet etal (2010). The study reported that principals used democratic or semi-democratic approaches with both teachers and prefects to handle various pertinent issues and used open communication channels to pass information to the rest of the student body. This resulted inthe high level of discipline found in the school.

Seeking student's views on important College issues is one thing and adopting their views and making it part of final decisions is another thing. Even though authorities in the three Colleges make effort to seek student's views, they hardly incorporate those views into decisions of administration. This is evidenced in Table 3 where majority of the respondents selected 'Disagree' and 'Strongly Disagree' (79\%) to the statement that student's views are incorporated into final decisions of College. Only $21 \%$ of the respondents cumulatively selected 'Agree' and 'Strongly Agree'. Apart from the general views where the respondents disagreed with the statement, each of the three Colleges also disagreed with the statement. That students' views are not sought for and their views, hardly incorporated in decisions of the College are supported by Jerunto et al (2011).

Views of tutors bordering on decision-making have been presented in Table 3. Tutors were also asked to express their views on the same issues posed to the students. First, tutors were asked whether they are well represented on College Council Committees. The responses were overwhelmingly 'Yes'. More than seventy percent of the respondents $(76.7 \%)$ held the view, whiles $23.3 \%$ disagreed with the statement. However, responding to the issue of College authorities seeking the views of tutors on important issues, $66.7 \%$ clearly disagreed with $33.3 \%$ agreeing. Again, the respondents rejected the statement that views of tutors are incorporated into final decisions of College (70\%).

It can be concluded from the responses of the three Colleges that; students are represented on College Committees, even though views of students and staff are sought in most cases in decision-making, the views are not incorporated in final decisions of the Colleges. Structures have been provided for both students and staff views but implementation of their views is the major problem as far as decision-making is concerned. The literature supports the finding that decision-making is delegated through committees set up to perform specific roles in the school (Glover, 2015). Further, Samkange, (2012) shares the views expressed by tutors that their views are hardly incorporated in decision-making of the Colleges. According to him, teachers would like to be involved in decision-making but the reality is that they are not involved in all areas of decision-making. The principal determines the active managerial climate and the amount of teacher and parents input in academic social spheres in school setting.

\subsection{College Finances}

College finances for this study have been looked at from two perspectives namely; SRC finances and College administration finances. Specific issues addressed in relation to the finances include; transparency, determination of SRC projects with SRC funds, and the role played by tutors in the determination of SRC projects by the use of SRC funds. Table 7 presents the views expressed by both students and tutors concerning the College Finances. 
Table 4: SRC/College Finances

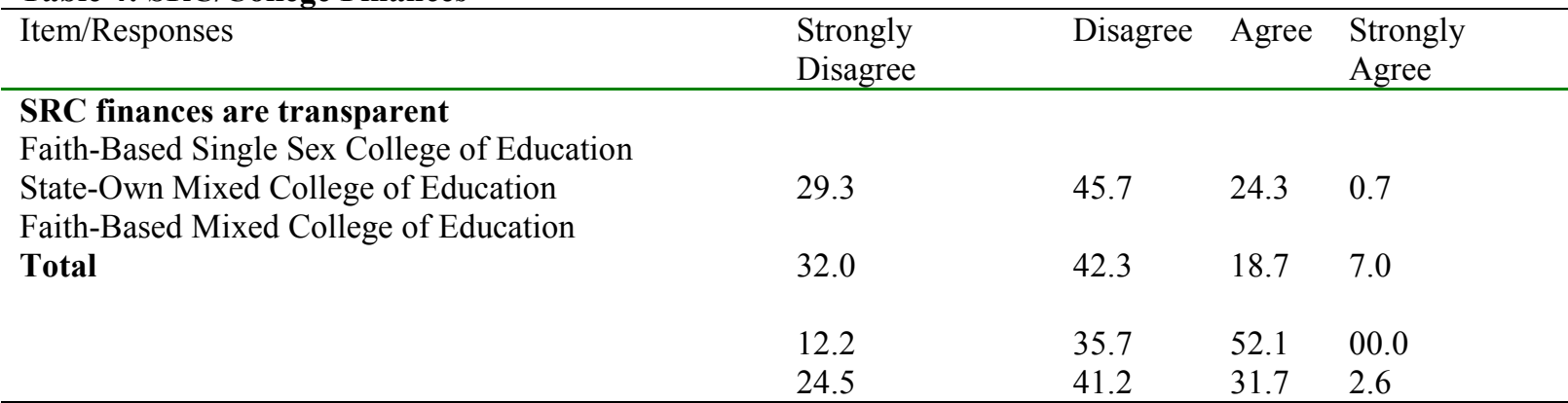

\section{Students determine their own project with SRC dues}

Faith-Based Single Sex College of Education State-Owned Mixed College of Education Faith-Based Mixed College of Education Total

$\begin{array}{llll}12.1 & 69.3 & 17.2 & 1.4 \\ 9.4 & 17.2 & 61.3 & 12.1 \\ 1.4 & & & \\ 7.6 & 2.9 & 82.1 & 13.6 \\ & 29.8 & 53.6 & 9.0\end{array}$

College finances are transparent to staff

Faith-Based Mixed College of Education State-Owned Mixed College of Education Faith-Based Mixed College of Education Total

\begin{tabular}{lllll} 
& 100.0 & 00.0 & 00.0 & 00.0 \\
\hline & 100.0 & 00.0 & 00.0 & 00.0. \\
& 93.3 & 6.7 & 00.0 & 00.0
\end{tabular}

Tutors play a role in determining SRC projects Faith-Based Single Sex College of Education State-Owned Mixed College of Education Faith-Based Mixed College of Education Total

$\begin{array}{llll}10.0 & 20.0 & 70.0 & 00.0 \\ 10.0 & 30.0 & 60.0 & 00.0 \\ 00.0 & 60.0 & 40.0 & 00.0 \\ 6.7 & 36.7 & 56.6 & 00.0\end{array}$

Source: Field Survey, (2020)

Responses presented in Table 4 indicates that first, SRC and College finances are not transparent to both students and staff (students $=65.7 \%$, tutors $=100 \%$ ). Secondly, trainees determine their own projects with SRC funds $(62.6 \%)$. Whiles trainees in SOMCOE and FBMCOE determine the SRC project to undertake with their funds, trainees in FBSSCOE do not determine what project to undertake but administration does. Thirdly, tutors do not play any significant role in the determination of SRC projects $(56.6 \%)$. Whiles in SOMCOE and FBMCOE students determine the project they want to undertake with their money by $73.4 \%$ and $95.7 \%$ respectively, trainees in FBSSCOE do not have the right to determine their own SRC projects (81.4\%).

The Colleges of Education cultural web derived from Johnson and Sholes (1992) categorizes College finances under control systems where budgets of students and College authorities are drawn from. This means the extent to which student leaders can undertake project for their year group to a great extent depend on the availability of money. Students should have the right to determine the kind of project they wish to undertake for the College using their own resources without any form of interferences by tutors. Principals could guide and offer suggestions but not to impose as per the routine in FBSSCOE. This is supported by Anaisie, (2016) and (Olangu), 2015 whose research identified principals and tutors' role in students' year group projects as domineering and dictating

\subsection{College Rules and Discipline}

School discipline is a required set of actions by a teacher towards a student (or groups of students) after the student's behaviour disrupts the ongoing educational activity or breaks a pre-established rule created by the 
school system (Anaisie, 2016). Discipline guides children's behaviour or sets limits to help them learn to take care of themselves, other people and the world around them. An obedient student is someone who obeys school rules and codes of conduct. These rules may, for example, define the expected standards of clothing, timekeeping, social conduct, and work ethic. The aim of discipline is to set limits restricting certain behaviors or attitudes that are seen as harmful or going against school policies, educational norms, school traditions, etc. Table 8 presents student's and tutors' responses on issues of discipline with regards to College rules and regulations. The core issues includes; respect and obedience to College rules and regulations, strictness of College rules and regulations, compulsory social gatherings of students and lastly whether tutors in the Colleges back and support the SRC in instilling discipline among students.

Table 5: College Rules and Regulations

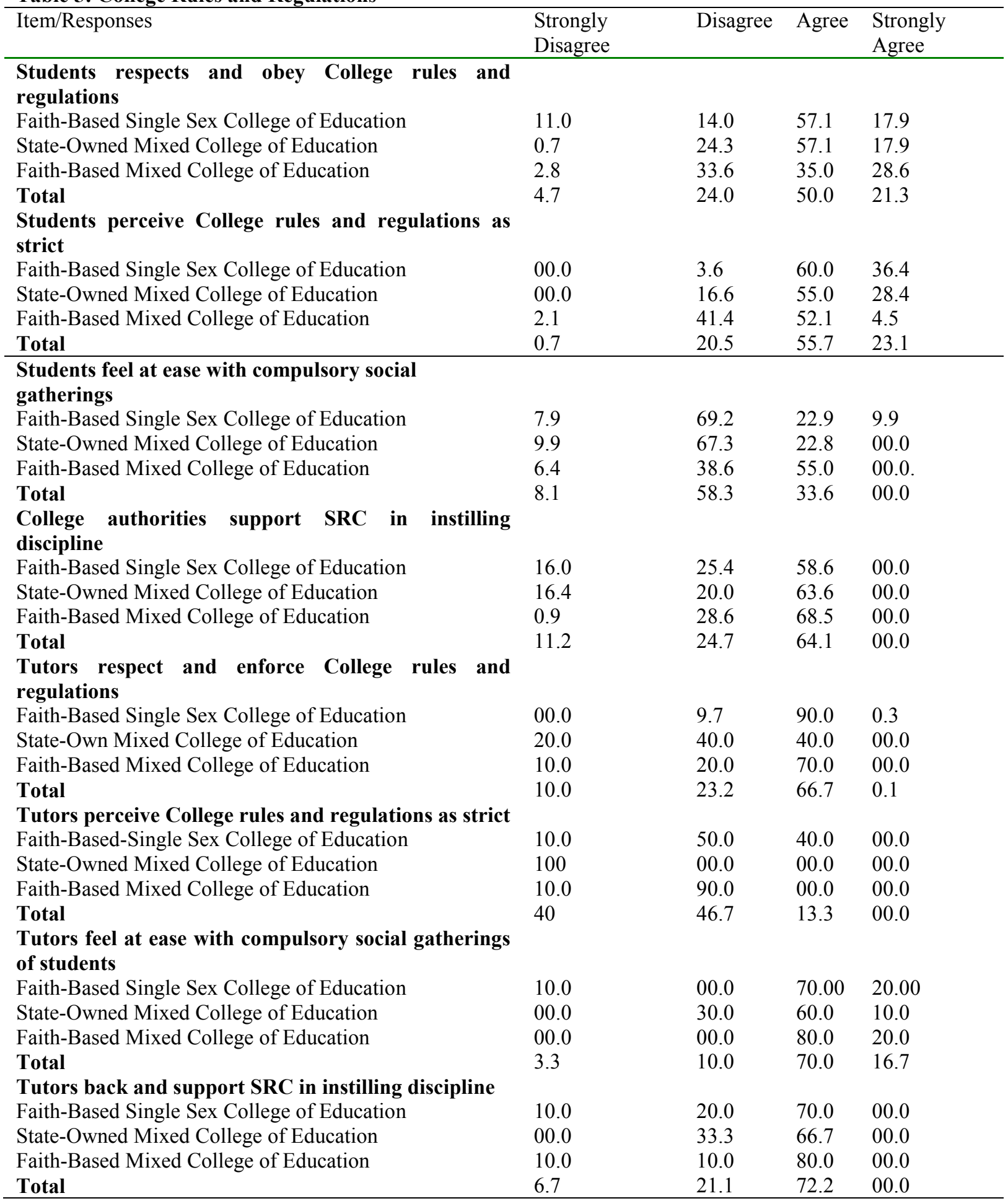

Source: Field Survey, (2020) 
Views of trainees and tutors were taken about College rules and regulations. The conclusions drawn from Table 5 are; Students and tutors in the three Colleges respect and obey College rules and regulations; whiles students perceive College rules and regulations as being strict, tutors do not have any problem with the rules and regulations in the College; students are not happy with compulsory social gatherings, whiles tutors do not have problem with compulsory social gatherings; Both students and tutors agree that College authorities back and support students leaders in instilling discipline.

These findings revealed by Table 5 indicates that $71.3 \%$ of trainees affirmed that trainees respect and obey College rules and regulations. On the part of the tutors, $(66.8 \%)$ also admitted that College rules and regulations are respected and enforced. The perception that College rules and regulations are strict were admitted by trainees $(78.8 \%)$ whiles tutors rejected the statement by $86.7 \%$. Trainees do not feel at ease with compulsory social gatherings $(66.4 \%)$ whiles tutors have no problems with compulsory social gatherings of students $(86.7 \%)$. Both trainees and tutors agreed with the statement that tutors back and supports the SRC in instilling discipline in students with $64.1 \%$ and $72.2 \%$ respectively. Students' views on strict College rules and regulations are consistent with Acheampong (2003), who assessed that many student teachers in the Colleges of Education felt that the strict College rules and regulations undermine their personal self-worth and freedom. Ollenu (2015) supports the findings on compulsory social gatherings and duties bemoaned by teacher trainees by indicating that weeding, scrubbing and all other manual work are considered as social duties for students. However, the Colleges of Education Cultural Web derived from Johnson and Sholes (1992) identifies the enforcement of College rules and regulations as part of the routines and rituals of Colleges of Education in Ghana.

\subsection{Mission and Vision Statements of the Colleges of Education}

The core mission of tertiary education according to UNESCO (1998) is to educate, to train and to undertake research. It is affirmed that the core missions and values of higher education, in particular the mission to contribute to the sustainable development and improvement of society as a whole, should be preserved, reinforced and further expanded. On the other hand, the main vision of tertiary education shall be on the grounds of equal accessibility to all on the basis of merit. As a consequence, no discrimination can be accepted in granting access to tertiary education on grounds of race, gender, language, religion or economic, cultural or social distinctions, or physical disabilities.

Equity of access to higher education should begin with the reinforcement and, if need be, the reordering of its links with all other levels of education, particularly with secondary education. Higher education institutions must be viewed as, and must also work within themselves to be a part of and encourage, a seamless system starting with early childhood and primary education and continuing through life. Higher education institutions must work in active partnership with parents, schools, students, socio-economic groups and communities (UNESCO, 1998). One of the conceptual strands of culture identified by Oyewu (2016) positions mission and vision statements of institutions under 'Paradigm' in the central sport of all the strands. This underscores how important they are. The mission and vision statements underscore the cooperative culture of each institution and epitomize the core values of the institutions as well. Table 6 presents how trainees and tutors responded to questions about the mission and vision statements of the Colleges of Education. 
Table 6: Mission and Vision Statement of my College

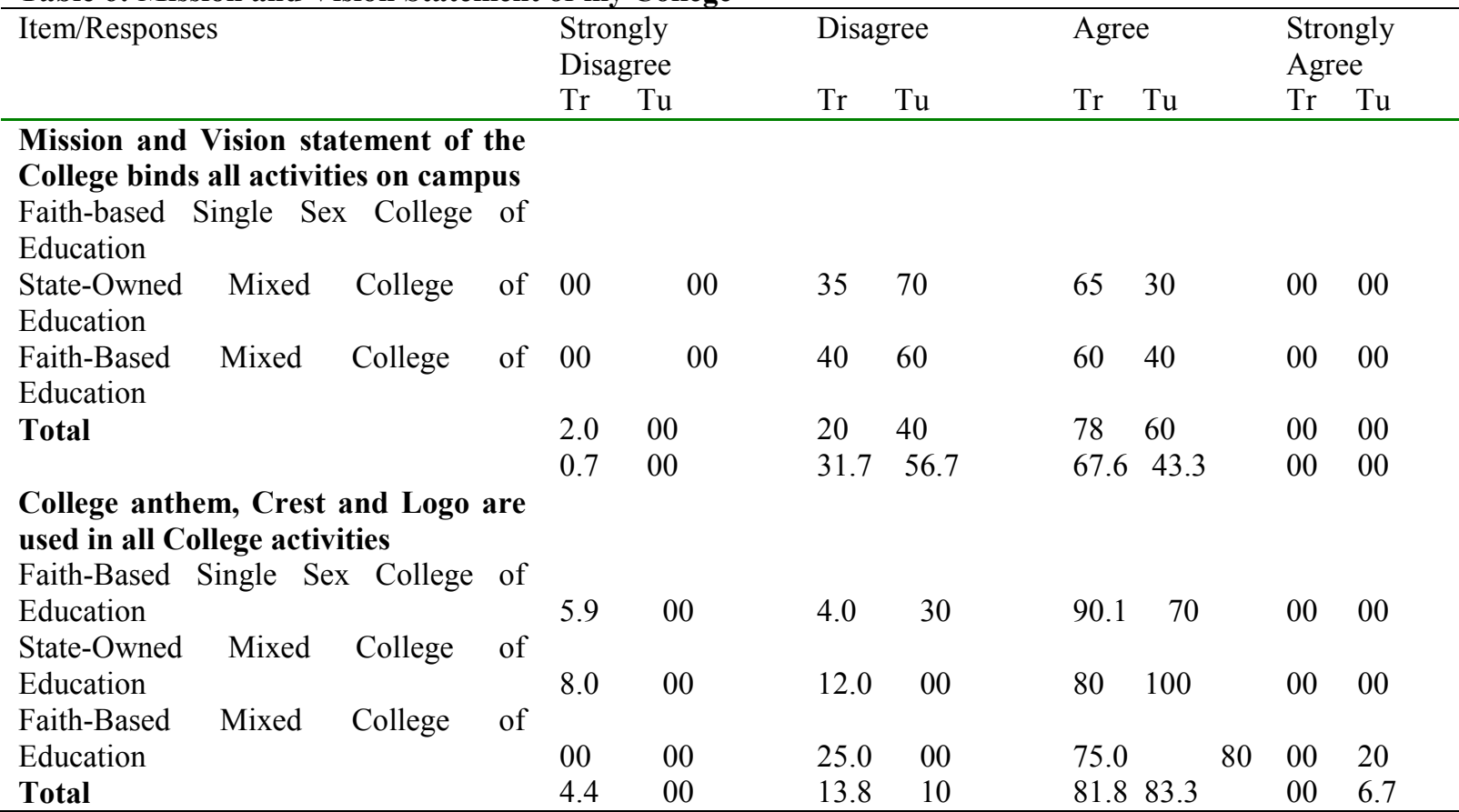

\section{(TR: Trainees; Tu: Tutors)}

Source: Field Survey, (2020)

The views of trainees and tutors were taken about the mission and vision statements of the Colleges of Education. Trainees in all the three Colleges agreed $(67.6 \%)$ to item one which sought to find out whether mission and vision statements of the College binds all activities. Tutors in the three Colleges of Education however, disagreed by 56.7 percent to the statement. The second statement sought to find out whether College anthem, Crest and Logo are used in all College activities. Responding, both trainees and tutors agreed by $81.8 \%$ and $90 \%$ respectively. The mission, vision, logo and all other symbols of institutions actually epitomizes their cultures which are also very necessary for institutional effectiveness. Supporting the stance taken by both students and tutors, Bipembi (2014) argues that a college's ethos, or belief system, is a predictor of institutional effectiveness. Micmack (2015) also suggests that culture, specifically, common values and symbols, serves as a nucleus around which institutions cohere. The fact that cultural elements such as crest, logo and anthem serve as agents of influences in an institution is aptly supported by literature. It is apparent that Ghanaian organizations place emphasis on their strategic planning and therefore are able to communicate their mission and integrate them in their organizational culture (Zakari, Poku \& Owusu-Ansah 2013)

\subsection{Achieving Quality Assurance in the Colleges}

Quality assurance is fundamental in the pursuit of quality in tertiary institutions and it is an important global trend. It has become essential in the world these days because of the acknowledgment that expertise capital that builds and sustains a country's national economy depends on the training offered by tertiary institutions (Cooper, 2002). The importance of quality assurance in tertiary education, undoubtedly has implications for the Colleges of Education. The upgrade of the teacher training colleges to the tertiary level by an Act of Parliament (Act 847) places them under the National Council for Tertiary Education (NCTE) and are therefore bound by the quality assurance requirements prescribed for all tertiary institutions that operate under the NCTE. The elevation of the Colleges of Education to tertiary level requires a more efficient management with emphasis on assuring quality. While the upgrade provides some privileges to the colleges such as institutional autonomy, it also makes the colleges more accountable to Government and the public in terms of performance. Thus, the survival of a College of Education will be contingent on the quality of its operations and also ensuring that minimum acceptable standards are in place in the institution. The symbolic dimension of quality places focus on cultural, interpretive and performance aspects of organisational practices (Berger \& Milem, 2000; Bolman \& Deal, 2008). Johnson and Sholes (1992) identifies quality assurance as one of the effective control systems through which the Colleges could achieve their mission and vision statements. Table 7 presents data on how students and tutors responded to items on quality assurance. 
Table 7: Quality Assurance Practices

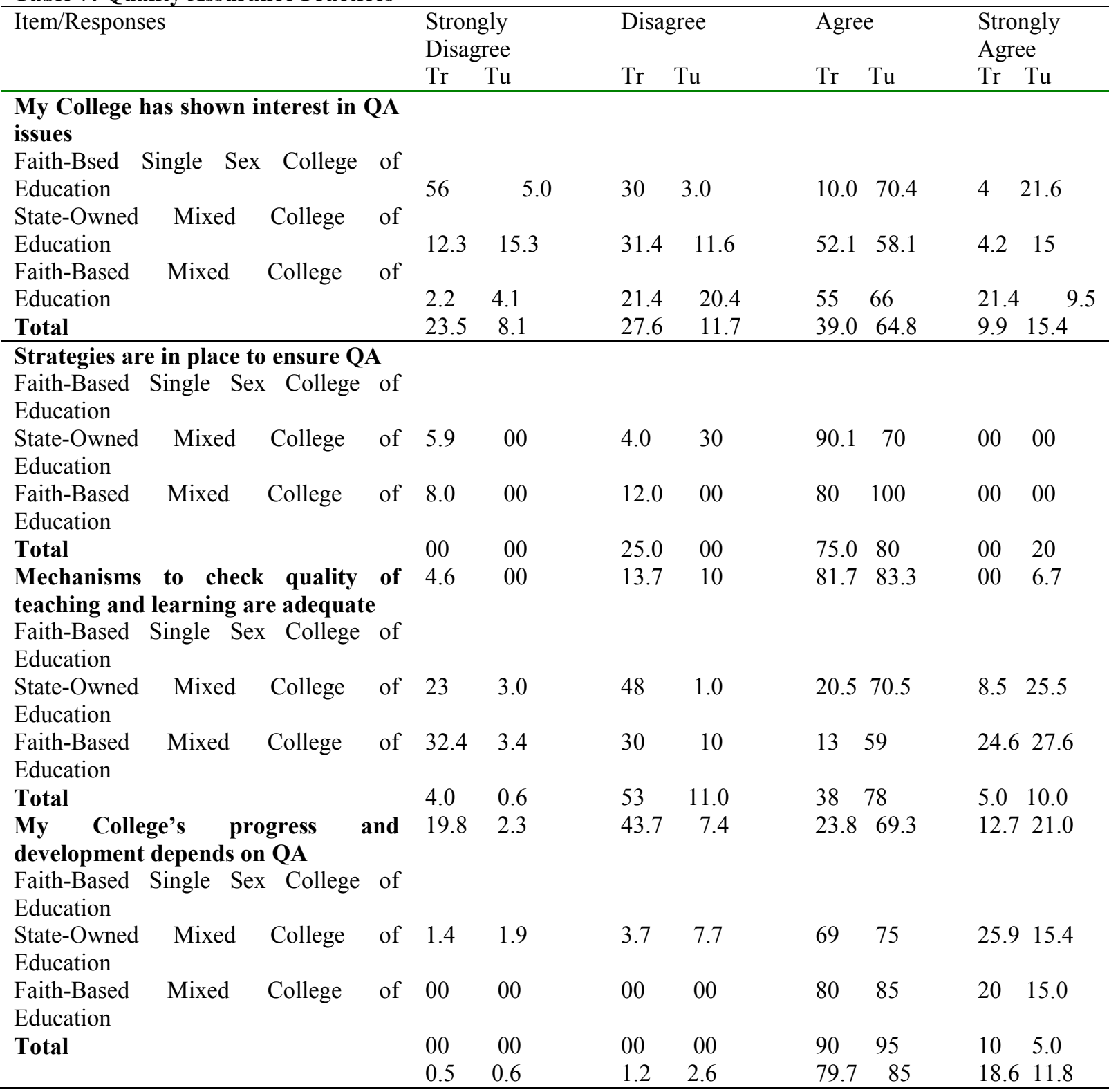

Source: Field Survey, (2019)

Quality assurance is a very significant aspect of every organisation. The progress of every organization depends on quality measures put in place to promote productivity. Students and tutors were made to respond to four quality assurance indicators in the Colleges. Views expressed by SOMCOE trainees (56.2\%) and FBMCOE trainees $(76.4 \%)$ agreed with the statement that their colleges have shown interest in quality assurance issues. However, respondents in FBSSCOE disagreed $(80 \%)$. However, tutors from the three Colleges affirmed the statement with a percentage view of 80.2. Concerning strategies put in place to ensure quality assurance practices in the Colleges of Education, both trainees and tutors responded in the affirmative with $81.7 \%$ and $90 \%$ respectively. The third issue is about whether mechanisms put in place to check quality of teaching and learning are adequate. Responding, trainees disagreed (63.5\%), whiles tutors agreed $(90.3 \%)$. The study also sought to find out from the respondents whether the progress and development of the College depends on the implementation of quality assurance measures. Both trainees $(98.3 \%)$ and tutors $(96.8 \%)$ agreed. In specific terms, trainees from SOMCOE (75.7\%) and FBMCOE (76.4\%) agreed that their Colleges have shown interest in quality assurance issues, while FBSSCOE trainees disagreed (86\%). Item 2 sought to find out whether strategies have been put in place to ensure quality assurance. Trainees from all the three Colleges agreed that strategies have been put in place to ensure quality assurance in the Colleges. The views of students from the three Colleges again came to a consensus on item three which sought to ascertain whether mechanisms to check quality of teaching and learning are adequate. Views of trainees about the relationship between College progress and quality assurance were in the positive. Students from the three Colleges overwhelmingly affirmed the statement 
that the progress of the College depends on quality assurance (FBSSCOE $=94.9 \%$; SOMCOE $=100 \%$; FBMCOE $=100 \%$ ).

The views expressed by both students and tutors in respect to quality assurance are supported by Aly and Akpovi (2001) who explained that, tertiary institutions also have realized that their long-term survival depends on how good their services are and that it is the quality of their services that will set one institution apart from the others. Stensaker, Brandt and Solum (2008) also noted that over the past two decades, the issue of quality assurance has been one of the major concerns in the area of higher education resulting in the establishment of quality assurance mechanisms for the assessment of teaching and learning. So the Colleges have put in place quality assurance mechanisms to promote quality. Organisational culture of each institution is counted as part of the measures aimed at checking quality of acitivities in the institution. These include College ethos, belief systems, campus life, curriculum and administration which serve as predictors of institutional effectiveness (Blay, 2015; Matorera, 2015 ;

3.8 Objective 2: The extent of tutors and students' adherence to the organizational culture related practices in the Colleges of Education.

Table 8: Means and Standard Deviations based on categorization of Organisational Culture-related Practices among the 3 Colleges of Education

\begin{tabular}{|c|c|c|c|c|}
\hline \multirow[t]{2}{*}{ Item } & \multicolumn{2}{|c|}{ Students' Views } & \multicolumn{2}{|c|}{ Tutors' Views } \\
\hline & Mean & $\mathrm{SD}$ & Mean & SD \\
\hline $\begin{array}{l}\text { Mode of selecting students' leaders/ Mode of } \\
\text { selecting HODs }\end{array}$ & 3.0 & 0.7 & 1.4 & 0.9 \\
\hline How the SRC operates/ How Tutors operates & 2.4 & 0.6 & 2.5 & 0.6 \\
\hline Decision -making & 3.4 & 0.9 & 2.4 & 0.7 \\
\hline SRC finances/College finances & 1.9 & 0.5 & 1.7 & 0.3 \\
\hline College rules and regulations & 2.6 & 0.5 & 2.7 & 0.4 \\
\hline Mission and vision statements of the College & 2.8 & 0.5 & 2.9 & 0.4 \\
\hline
\end{tabular}

Source: Field Survey, (2020)

Categorization of organisational culture related practices captured in Table 8 gives the Group Means and Standard deviations of the three Colleges. In arriving at the group means of the categorization of organisational culture-related practices, individual means were computed. The basis for using the mean and standard deviation in discussing the organisational culture-related practices was to give a clear picture of how the respondents viewed each practice. So whilst the mean gave an accurate description of the views, the standard deviations indicated how spread or closed the views of the respondents were.

With regards to the Mode of selecting students' leaders, students from the three Colleges agreed that their SRC leaders were selected by elections. The tutors on the other hand disagreed that their HODs were elected by departmental members. On the second item concerning how the SRC/ Tutors operate, both students' and tutors' views were "Moderate". The Mean values were 2.4 and 2.5 respectively. This suggests that even though students and tutors have their freedoms to operate, they are however, subjected to some limitations by College authorities. For example, earlier discussions indicate both students and tutors are part of College Committees but as to whether their contributions or decisions are engrafted into the ultimate decisions of the College are left only to the jurisdiction of the Principals of the Colleges.

Students' Mean for "Decision-making" is higher than that of tutors (Students' Mean= 3.4, SD=0.9, Tutors' $=2.4, \mathrm{SD}=0.7$ ). This means students have been given more rooms to participate in decision-making in the Colleges than tutors. Even though there are degrees to which they could be involved in decision making among the three Colleges used for the study.

SRC finances and College finances recorded the lowest Mean in all (Students Mean= 1.9, SD=0.5, Tutors' Mean=1.7, $\mathrm{SD}=0.3$ ). The figures explain the lack of transparency in the finances of the SRC in particular and that of the College in general. The Standard deviations are also closely scattered). Item 5 "College rules and regulations" recorded a Mean of 2.4 for students and 2.5 for tutors. The implication is that both students and tutors have similar views concerning the rules and regulations in the various Colleges. The popular view held is "Students respects and obey College rules and regulations". However, issues concerning the strictness of rules and regulations were upheld by students whiles on the part of tutors they rejected the statement that College rules and regulations were strict. Issues concerning strictness of rules and regulations upheld by students is supported by Adams and Opare (2013). According to them, students' lack of commitment to their alma mater is as a result of their dissatisfaction with the organisational culture of the College which is predominantly showcased in restricting students' outings, engaging students in manual work such as scrubbing and weeding.

"Mission and Vision Statements of the College" attracted a mean value of 2.8 for students, and 2.9 for tutors. The Standard deviations were 0.5 and 0.4 respectively. The mean figures are "High" which implies that 
both Tutors and students attach seriousness to their Mission and Vision statements and operates being guided by them.

3.9Objective 3: Differences in teacher trainees' views of organizational culture related practices among the Colleges of Education

Table 9: Analysis of Variance Comparing Teacher Trainees' Views of Organisational Culture-related Practices among the 3 Colleges of Education

\begin{tabular}{lccccc}
\hline $\begin{array}{l}\text { Teacher Trainees' views } \\
\text { of College practices }\end{array}$ & Sum of squares & Df & Mean Square & F & Sig. \\
\hline & & & & & \\
Between Colleges & 4.596 & 2 & 2.298 & 8.597 & 0.000 \\
Within Colleges & 119.204 & 446 & .267 & & \\
\hline
\end{tabular}

Source: Field Survey, (2020)

ANOVA was used to determine whether the views were significantly different. The results in Table 9 indicate that there were differences in teacher trainees' views on College Practices among the three Colleges. The statistics show that: $(\mathrm{P}<0.05, \mathrm{~F}=8.597$, and $\mathrm{df}=446)$. Notwithstanding the significant differences, eta square was calculated to determine the effect size of the relationship which yielded a coefficient of 0.4. The effect size (eta squared $=0.4$ ) indicates a moderate difference. Though the effect size is moderate it gives some indications about the differences in the means of the three Colleges

\subsection{Conclusions and Recommendations}

The major issue which the study focused on was Organisational Culture-related Practices. Seven practices were identified and discussed. They were; 'How leaders are selected and oriented, how trainees and tutors operate, decision-making, SRC/College finances, College rules and regulations, mission and vision statements and quality assurance. Similar and varied views were expressed by both tutors and trainees from the three Colleges of Education.

In the first place concerning the mode of selecting student leaders, the study revealed that Students' Representative Council leaders (SRC) are elected through general elections (54.5\%) whilst heads of departments are selected through appointment by the College principal $(100 \%)$. Leadership training is offered to elected students' leaders in all the Colleges whilst on the part of the tutors, $76.7 \%$ rejected the statement that mentorship training is offered to tutors.

Secondly, a number of findings were established about ways by which the SRCs of the Colleges operate as well as how tutors in the Colleges also work. Three key issues discussed includes; enforcing rules and regulations, working without staff supervision and freedom to express oneself freely on administrative issues. Students and tutor respondents unanimously attested to the view that they both have authority to enforce their decisions as well as rules and regulations of the College (Student: 52.2\%; tutors: 56.6\%). Students' leaders could work with little or no staff supervision (52.2\%). Tutors on their part could generally express themselves freely on administrative issues without restrictions $(60 \%)$. The specific finding however is that whilst in SOMCOE and FBMCOE tutors can express themselves freely (SOMCOE: 60\%; FBMCOE: 80\%), the reverse is the case in FBSSCOE (60\%).

Thirdly, concerning decision-making, the following were established: Students and tutors were adequately represented on College Committees and Council Committees by percentage views of 71.8 and 76.7 respectively. It came to light that views of students and tutors on important issues are not sought for by College authorities (student: $61.1 \%$; tutors: $67.7 \%$ ). Again, the study revealed that views of students and tutors are hardly incorporated into final decisions of College management (Students: 79\%; Tutors: $70 \%$ )

Fourthly, three findings were made about College and SRC finances. Whilst SRC finances were found to be transparent (65.7\%), College finances were found to be non- transparent (93.3\%). Annual SRC projects financed by SRC funds are not wholly determined by the SRC (62.6\%). Tutors however, play a role in determining SRC projects $(56.6 \%)$.

Fifthly, four specific findings were made in respect to College rules and regulations. Students were found to obey College rules and regulations (66.8\%) whilst tutors were also found to strictly enforce College rules and regulations (66.8\%). Again, students perceived College rules and regulations as strict (78.8\%). Tutors on the other hand did not see anything wrong with the College rules and regulations $(86.7 \%)$. On compulsory social gatherings, it came out that students did not feel at ease with it $(66.4 \%)$ whilst tutors did not have problem with compulsory social gatherings (86.7\%). It also came to light that College authorities support the SRC in instilling discipline (72.3\%). The sixth finding was that the Mission and Vision statements of the Colleges including anthem, crest and logo are actively used in all the Colleges of Education.

The seventh group of findings centred on quality assurance practices in the Colleges of Education. The studies outcome indicated that whilst students disagree (51.1\%) with the assertion that the Colleges of Education 
have shown interest in quality assurance issues, tutors agreed $(80.2 \%)$. With regards to strategies put in place to ensure quality, both students and tutors agreed by $81.7 \%$ and $90 \%$ respectively. However, it was found from students' perspective that mechanisms to check quality of teaching and learning are inadequate (62.5\%). College's progress and development were also ascertained to depend on quality assurance by both students and tutors by $98.3 \%$ and $96.8 \%$ respectively.

The findings that emanated from the organisational culture related practices in the target Colleges of Education can be well situated in the concept and the theories of organisational culture as espoused by Schein (1992); Mallet and Gee (2014) and Martins and Martins (2003), who agree that organisational culture involves shared beliefs, values and ways of doing things in an organisation which motivates people to perform their roles in various ways. From the findings, Colleges of Education have their own culture and have well established routines which bind members. The discussion revealed that issues concerning; modes of selecting leaders, decision-making, college rules and regulations, commitment to mission and vision statements and quality assurance practices were held in high esteem by the Colleges of Education. This agrees with the theories of organisational culture which indicate that each organisation is unique and that all organisations have peculiar characteristics which make them out.

\section{REFERENCES}

Acheampong, K. (2003). Teacher training in Ghana - does it count". London: DFID Educational Paper Series.achievement. Learning Media and Technology, 30, (1), 15-25.

Adams, F.H. \& Opare, J. A. (2013. Students' perception of the organisational culture of their schools as a correlate of their commitment to the school. African Journal of interdisciplinary Studies, 6, (1), 73-82.

Aly, N. \& Akpovi, J. (2001) Total Quality Management in California Public Higher Education. Quality Assurance in Education, 9, (3), 127 -131.

Anaisie, B. (2016). Routine practices of college students. International Journal of Quality Intervention. 3, (2), 23

Appiah, A. M. (2012). Students' leadership in tertiary institutions. Retrieved from www.theplatform.gh/schools.com.

Arshad, M. (2003). A study of organisational culture and effectiveness of Secondary Schools. Unpublished Doctoral dissertation. University of Punjab, Lahore

Berger, J. \& Milem, T. (200). Organisational Behaviour in Higher Education and Students' Outcomes. Higher Education Handbook of Theory and Research. Xv, 268-338

Bipembi, E. (2014). Relationship between leadership style and school climate. Management Journal, 6 (2), 4-7

Blay, F. (2015). The Role of Culture and leadership in institutions of learning. Journal of Interdisciplinary Studies, 8 (2), 6-8.

Bolman, L. G., \& Deal, T. (2008). Reframing organizations; Artistry, Choice, and Leadership. San Francisco: Jossey-Bass.boundless.com/sociology/

Colleges of Education Act, (2012). Act 847. GPCL/A397/350/4/2012.

Cooper, F. (2002). Africa since 1940. Cambridge, UK: Cambridge University Press.

GES, (2010). Ethics of the teaching profession espoused. Retrieved from www.ghanaeducation.gh on 27-08-14

Glover, A.A. (2015). Student participation in Decision making in Senior high Schools in Ghana. PH. D Thesis

Gursel, M. \& Negis- Isk, A. (2013). Organisational culture in a successful primary school: An Ethnographic case study. Journal of Educational Sciences: Theory and Practice, 13,(10), 221-228

Harmonised Statutes of Colleges of Education, (2013). Retrieved from www.ncte.edu.gh on 05-07-14

Jabir, M. \& Majir, H. (2015). Impacting School Organisational Behaviour with leadership. Journal of Organizational Ethics, 8, (4), 14-17

Jeruto, T.A., Amock, P., \& Brand, S.(2011).Extent of Student participation in Decision-making in Secondary Schools in Kenya. International Journal of Humanities and Social Science. 1 (21)

Johnson and Sholes (1988). The Cultural Web. fromhttps://www.mindtools.com/pages/article/newSTR_90.htm on 05-05-14

Kapp, C., A.(2000). Leadership development for educational leaders: from needs assessment to impact evaluation. South African Journal of Education, 20:286-292.

Kibet, M.J., Kindiki, J.K, Kitilit, J.K \& Sang, J.K. (2012) Principal leadership and its impact on students' discipline in Kenya Secondary schools: a case of Koibatek district. Nkanyiso, Jnl Human and Soc Sci, 2(2)

Kruger (2003). Instructional leadership: the impact on the culture of teaching and learning in two effective Secondary Schools. South Africa Journal of Education, 23,(3), 206-211

Kumar, K. K. (2011). Climate and change initiatives effort. Change Efforts, 32, (7), 9-12

Lumpkin, A. (2008). Teachers as role models teaching character and moral virtues. Journal of physical Education and dance, 79, (2), 20- 22

Mallet, T. P. and Gee, M. (2014). Measures of success in education. Periodic Planner, 2, (1), 4-9 
Martins, N. \& Martins, E. (2003). Organisational culture Cape Town: Pearson Education South Africa.

Martorera, D. (2015). Conceptual Analysis of Quality function Deployment-Based Contexts of Higher Education. Journal of Education and Practice, 6, (33), 145-156.

Mentz, P.J. and Westehuizen, P.C. (1992). Applicability of the organisational Climate Description Questionnaire- Rutgers Elementary: A south African case study. South African Journal of Education; 33,(3).

Micmack, S. (2015). Culture Dynamics. Retrieved on 13-2-17 from www.culturalinformation.com/dynamics

Mintah, S. (2013). Social work: Organisational commitment. Lagos, Misland publications

Mireku, D. K. (1998 ). Demand and Supply of Basic School Teachers in Ghana

Mondal, P. (2016). Top 5 theories of social change. Retrieved on 5-2-17 from www.yourarticlelibrary.com

Olangu, K. (2015). Leadership and Quality Assurance in Higher institutions. Institutional Forcast, 5,(3),16-118

Oyewu, F. (2016). Making the school more responsible. International Journal of Empirical Studies, 5, (15), 4246

Samkange, W. (2012). Teacher involvement in decision making; A case for school Administration and Management in Zimbabwe. International Journalof Social Science and Education. l 2, (2), 32

Schein, E. H. (1992). Organisational culture and leadership (Second Edition ed.). San Francisco: Jossey-Bass Publishers.

Stensaker, B., Brandt, E., \& Solum, N. H. (2008). Changing systems of external examination. Quality Assurance in Education, 16, (3), 211-223.

UNESCO, (1998). “World Declaration on Higher Education. The Twenty-First Century: Vision and Action”, adopted by the World Conference on Higher Education.University Rationalization Study, (1988) II. Final Report

Yadessa, M. (2014). Assessment of School Climate and Leadership Practices: The case of four selected secondary schools of Eastern Haraghe Zone, Ethiopia. Journal of Education and Practice. 5, (37)

Zakari, M., Poku, K. \& Owusu-Ansah, W. (2013). Organisational culture and Organisational performance: Empirical Evidence from the banking Industry in Ghana. International Journal of Business, Humanities and Technology, 3,(1), 101. 